\title{
THE INTEGRATED RENOVATION OF HIGH-RISE HOTELS ON THE SPANISH MEDITERRANEAN COAST
}

\author{
V. ECHARRI, F.J. ALDEA, J.G. GÓMEZ, \& J. ROMERO DEL HOMBREBUENO \\ University of Alicante, Spain
}

\begin{abstract}
In terms of construction and energy efficiency, Spain has one of the highest indexes of obsolete buildings among the developed countries. In the case of high-rise hotel buildings, this problem is further added to by the low levels of safety in the case of fire. The development of tourism in the 1950s and 60 s led to the construction of a large number of high-rise hotels with $30+$ floors. Initially, they conformed to lax, undemanding regulations regarding fire resistance in their structural components, fire escape routes, protected staircases, and so on. The requirements of today's regulations in this field, contained in the Basic SI Technical Building Code Document, often make the renovation of these buildings an impossible task. Installing specially protected staircases can entail traumatic modifications that are sometimes unviable due to structural conditions or economic considerations. Furthermore, the building's energy efficiency and $\mathrm{CO}_{2}$ emissions do not correspond to environmentally-friendly practices. This paper examines the above questions with regard to the Hotel Tryp Gran Sol in Alicante, Spain. The hotel is $97 \mathrm{~m}$ high and has 31 floors. The integrated renovation of the hotel requires serious reflection upon the building's global response to personal safety, its envelope components and its air conditioning. Architectural solutions and the building's economic viability for future exploitation as an important element in the building's life cycle assesment (LCA) are discussed.

Keywords: construction and demolition waste, energy efficiency, environmental impact, life-cycle assessment, safety in case of fire.
\end{abstract}

\section{INTRODUCTION}

The increasing trend of scant availability of resources and excess construction and demolition waste (CDW) needs to be redressed through sustainable cities and architecture. Sustainability could be defined as 'the quality of satisfying present needs without comprising the capacity of future generations to satisfy their own' [1]. Three factors call for optimism in this area, the dissemination of ecological awareness, communications technology and automated production [2]. We note with some concern how CDW is continuously increasing compared to levels of reuse, while, given the exploitation of material and energy resources, it could be concluded that the current way of life in our cities is unviable. Any person venturing to analyse our cities' relationship with the environment will discover the complexity of all the numerous factors involved and their influence on aspects such as energy efficiency, water management, environmental and acoustic pollution, flexibility, communication or management of built property and so on. The use of material resources and their recycling merits a chapter alone, in addition to terms such as 'reduce, rethink, reuse', successive transformations or reduction of their environmental impact when disposing of materials [3].

Recent technological developments are currently enabling improved use of resources, significant energy savings and a greater percentage of use of renewable energies, optimisation 
of resources through industrialisation and prefabrication processes, and waste treatment better suited to our ecosystems. It would be an error a priori to assume that technological development and sustainability are incompatible goals. What is important is knowing how to develop the appropriate technology in each case, integrating it in the project procedure, taking into account the costs of installation, exploitation, savings, coefficients or energy production, maintenance costs, disposal costs of the equipment or systems used etc. [4]. In this regard we share Yeang's thesis which holds that the systems proposed should result from the integration of natural and technological systems, and their aesthetic aspect should be subordinate to the requirements of this bio-integration [5].

\section{RENOVATION OF HOTELS AND SAFETY IN THE EVENT OF FIRE}

Spain has a stock of 14.5 million obsolete buildings together with their respective spaces and public facilities are on the point of collapse, and they fail to comply with the minimum standards of efficiency, comfort and quality that current regulations require. Clearly, renovation - regeneration of the present building stock - will increase in importance from now on, particularly if we consider that renovation may become a cyclical phenomenon with new regeneration required every 25-30 years. Furthermore, the energy efficiency of many of these buildings is clearly deficient, a factor which has negative repercussions on comfort in some areas of these buildings, and on their energy consumption and operating cost.

Renovation has always been seen as a way of recovering the lost activity of historic centres, mainly in the tertiary sector although this alternative has not always been effective or at times has been disastrous. In this regard, intellectual efforts are needed to rethink and reuse the building resources of cities, both historic centres and their more rundown neighbourhoods. And this should be done from the perspective of sustainability to revitalise urban centres and to leave a viable inheritance to future generations.

The renovation of hotel buildings located in historic city centres is a priority both for ongoing economic activity and to breathe life back into derelict historic centres. In the case of the Spanish Levant, many hotels that were built in the 1960s urgently need complete reforms with fire safety and protection a crucial aspect of this process. Many of these hotels are high-rise buildings often exceeding 20 floors with significant drawbacks in terms of fire escape stairways and evacuation routes, water tanks for extinguishing fires in the upper floors, etc. Recent events in Dubai, for example, reminded us all of the risks of fire in highrise buildings that seriously endangered the lives of many people. In addition, these buildings create considerable difficulties when installing new amenities and services due to the lack of technical facilities and the clearance height between floors. Replacing the air conditioning with more energy efficient systems is sometimes technically unviable, or is so expensive that the investment is not cost effective [6,7].

\section{LCA AND SAFETY IN THE EVENT OF FIRE: HOTEL GRAN SOL}

Following implementation of Directive 2010/31/EU, buildings are required to be more energy efficient and have less environmental impact during their useful phase. According to Hernández and Kenny [8], the life cycle methodology could be the most appropriate for assessing environmental and economic impact of buildings from 2018. This research does not propose a Life Cycle Assessment (LCA), nor does it intend to study the other stages from the cradle to the grave of buildings, but instead it proposes to analyse the terms rethink, reuse, reduce, reuse, recycle, as applied to these high-rise hotels. We propose to focus on something 
which is difficult to quantify even as part of an LCA, namely personal safety in the event of fire and preservation of the artistic values of the building. For this purpose, we shall leave aside indicators that have a determining impact when applying LCA, in its stages of production-transport, start-up execution of works, maintenance, demolition and reuse-replacement.

Recent research has shown how the LCA methodology can and should be simplified. Its extreme complexity makes it unviable for small-scale or PEM interventions and at times the significant number of indicators analyse imply repercussions on the environmental impact lower than 1\% [9]. Therefore, this research on high-rise hotel restoration proposes to concentrate on some impact indicators which have a greater percentage of environmental impact. They are environmental - construction and demolition waste CDW, reduction of primary energy, reduction of energy demand, and Economic - return on investment, life cycle cost analysis.

This research looks at a hypothetical renovation of the hotel Gran Sol Tryp Alicante, situated just a few metres from the Mediterranean coastline. It was built in 1971 and has 31 floors and a surface area of $164 \mathrm{~m}^{2}$ per floor. There are only five rooms on each floor. The total built area is $5,084 \mathrm{~m}^{2}$, with a total of 123 rooms. It was partially renovated in 1998, and in 2003, it underwent a complete overhaul. The single fire escape staircase was not specifically protected, but was in fact open to the areas it served. The hotel lacks a technical facilities floor where fire extinguishing water tank could be located at height to help with extinguishing fires. The air conditioning systems are obsolete and inefficient in terms of energy consumption. The building has an enormous mural of artistic value created by Manuel Baeza on its inner façade. The specific features of the building unquestionably affect the application of the LCA methodology. Making the building safe from fire and preserving the existing mural seems to be intangible values which would affect the priority and simplification of impact indicators in any action that would ensure preservation of the environment.

\section{STRATEGIES AND GOALS}

1. Compliance with the regulations and standards of Fire Protection CTE DB-SI. As the building dates from the 1960s, it does not comply with current fire prevention regulations. One or two specially protected fire escape stairways are proposed.

2. Energy renovation of the building through the implementation of new, more efficient air conditioning installations. The environmental impact of the building during its life cycle will be taken into account.

3. Application of ceramic material in the façade conserving the original murals dating from the building construction. A mixed construction system comprising parameterised ceramic and FINSA metal fabric is seen to be an ideal solution as it is lightweight, with good performance and rapid execution.

4. Conservation of as many architectural features as possible, fully respecting the building structure, ensuring that the minimum amount of CDW waste is generated for dumping.

5. In order to improve the quality of the hotel for its users, it was decided to take action in respect of the total accessibility of the building.

6. The building's performance in terms of thermal load through new air conditioning installations (heating+systems VRV+ air renewal). Thermal comfort and energy efficiency are the second priorities of the building refurbishment project. 


\section{PROPOSALS FOR SAFE ACTION IN THE EVENT OF FIRE}

An analysis of the Hotel Gran Sol Tryp highlights the shortcomings of its fire safety measures. While the building complies with equipment and installations in terms of requisite protection in accordance with current regulations (CTE DB-SI 5), there are other basic requirements which fail to comply with standards due to the out of date execution: interior spread of fire (DB-SI 1), evacuation of occupants (DB-SI 3) and the structure's fire resistant properties (DB-SI 6). Furthermore, due to the complexity and dimensions of the building, other aspects such as the intervention of the fire service (DB-SI 5), are almost impossible to fulfil given the building geometry and the hotel's location in the urban grid.

The building's current fire escapes (Fig. 1) are extremely ineffective, as given their height - more than $28 \mathrm{~m}$ - there should be two protected and ventilated exits per floor. The main staircase runs through the central part of the building round the lift, with dimensions which are well below those permitted $(0.8 \mathrm{~m}$ as opposed to $1 \mathrm{~m})$ and without sectorisation or ventilation. The emergency staircase, situated on the north corner, is sectorised and ventilated, however, its outline and route are confusing, and it fails to comply in terms of width. The lift shafts do not help either as they are small (four people), and they are located in a somewhat random manner.

Making the hotel safe in the event of fire could be implemented through two differentiated strategies [10]. The first -GS-1- consists of introducing a specially protected staircase in the south-west corner, currently used as a service staircase, office and toilets for personnel (Fig. 2). It would not comply with the CTE DB-SI, but it would provide a significant security boost with minimum demolition of construction elements and floor slabs. The second -GS-2is proposed as it complies with CTE DB-SI in all its requirements, as contained in Tables 1, 2 and 3. Two new staircases would be built, one protected and another specially protected with two evacuation routes (Fig. 3) [11]. In order to comply with the minimum dimensions, the landings of these stairways would be raised over the original façade. This option entails further demolition of construction elements, as well as an important part of the south west façade. In this way, the $900 \mathrm{~m}^{2}$ mural by Manuel Baeza would disappear. Recovery of the mural and the original aesthetic aspect of the building have been inspired by the Flexbrick [12] system. This could be resolved with FINSA stainless steel fabric and parts made from lightweight porcelain stoneware affixed in the form of mosaic tiles. The possibility of using printer inkjet enamelling technique would faithfully reproduce the colour range of the existing mural. Also, it would reduce the environmental impact of the façade.

These two options could be combined with the layout of a technical facilities floor in the building. The specially protected staircase would run from the 7 th to the 31 st floor. The technical facilities floor would be located on the 16th floor. For this purpose, the partitions and wet rooms on that floor would be demolished. Water tanks would be installed with pressure equipment for fire extinguishing purposes. Other similar tanks would be provided on the building roof, increasing the capacity of existing supplies by 60,000 litres. This structural overload would be compensated with the reduction of weight obtained by replacing the façade with the FINSA fabric and the ceramic mosaic. For each floor, there would be 5.5 linear metres, that is, $14.85 \mathrm{~m}^{2}$ or $2.97 \mathrm{m3}$, with a weight of $6.12 \mathrm{Tm}$. With a total of 24 floors, this would reduce the load by $146.88 \mathrm{Tm}$. The weights of the existing flooring and floor slabs would be similar to the new stairs installed. In this way, with some structural reinforcements based on carbon fibre, three tanks holding 10,000 litres could be installed on the roof, and a further 310,000 litre tanks could be installed on floor 16. This technical plan would be ideal for introducing a new air conditioning system based on an 


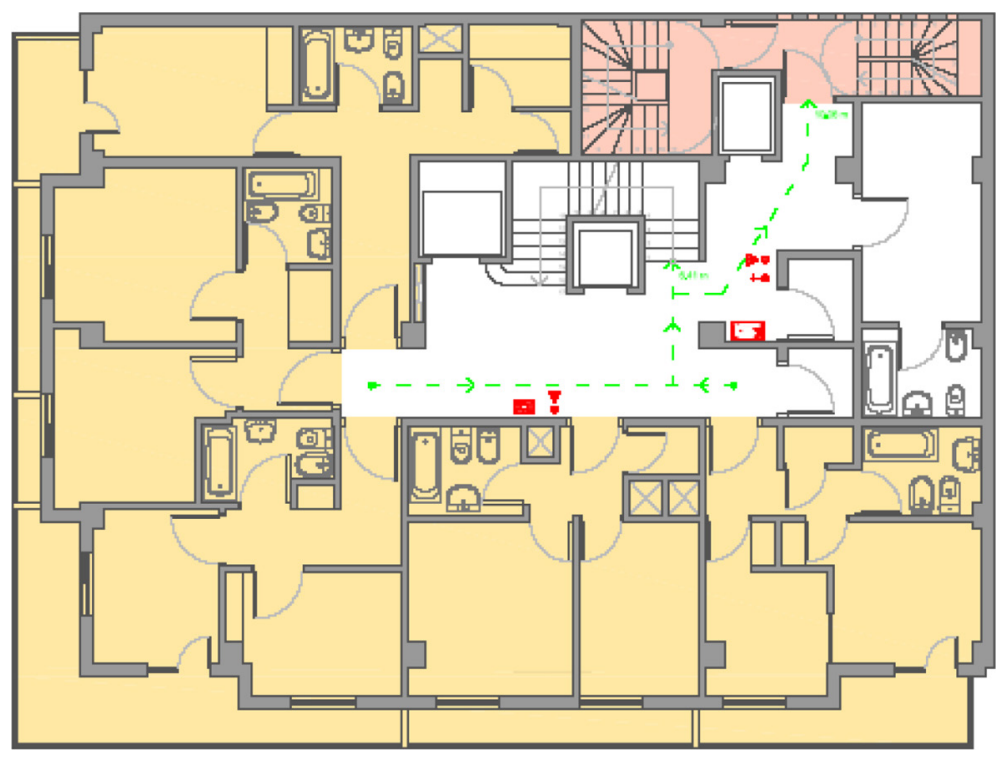

Figure 1: Typical view of hotel. Current state.

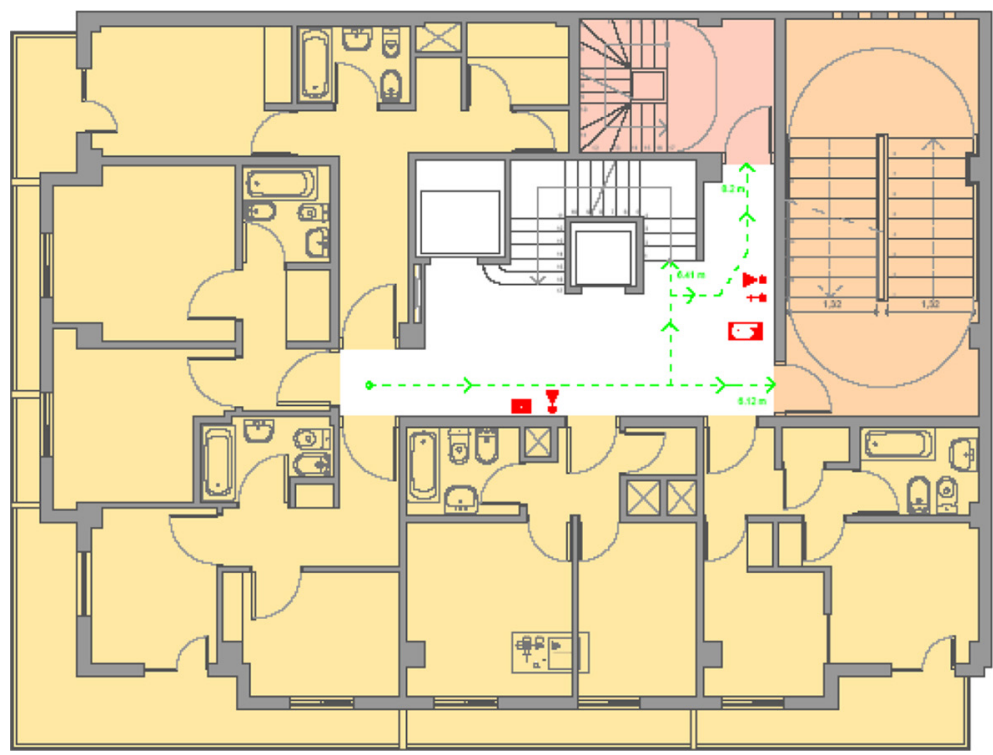

Figure 2: GS-1 modified floor with a new fire escape.

all water installation with $2120 \mathrm{~kW}$ heat pumps on each technical facility floor and fancoil terminals in all rooms. Semi-centralisation of the installation and greater proximity to the terminal elements would make it more energy efficient, flexible and easier to maintain properly [13]. 


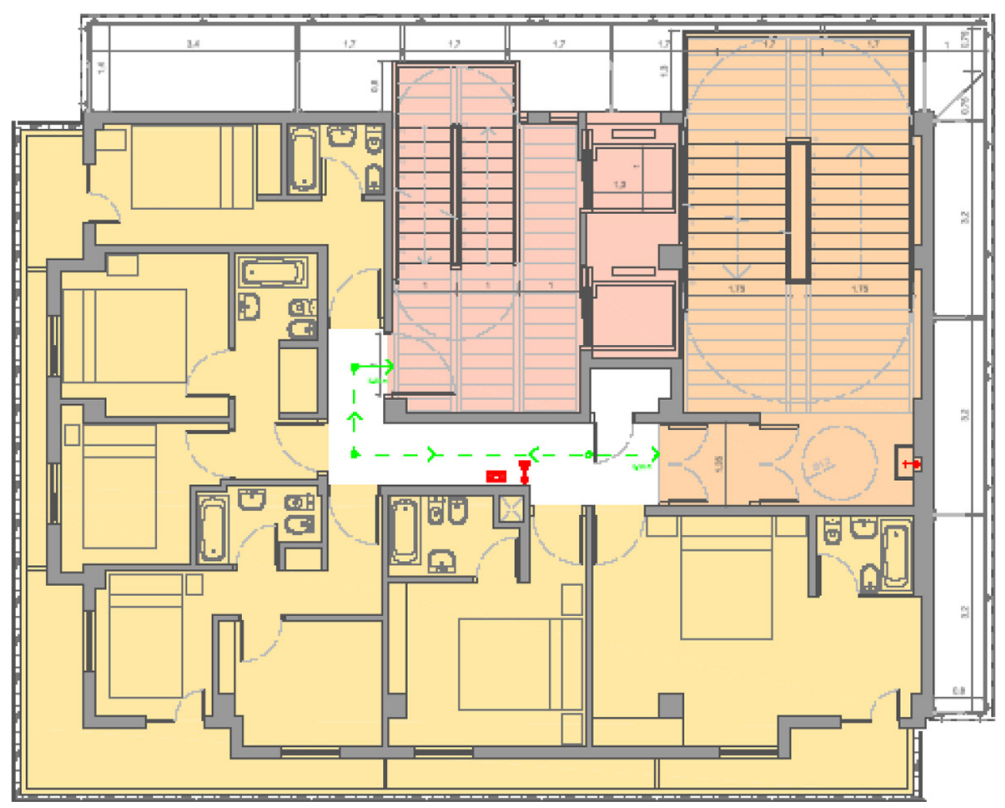

Figure 3: GS-2 modified floor with two new fire escapes.

Table 1: Calculation of parameters according to use.

\begin{tabular}{lccc}
\hline Área $\left(\mathbf{m}^{2}\right)$ & & 1 floor & Total \\
\hline Built & & 164 & 5,084 \\
Useful (with protected staircases) & 147.6 & $4,575.6$ \\
Useful (without protected staircases) & & 87 & 2,697 \\
Occupation & Floors & $\mathbf{m}^{2}$ & Persons \\
\hline Hotel (Use Residential public) & 18 & $1,566.0$ & 78.3 \\
\hline Floors with rooms & 1 & 35.0 & 0 \\
35 m $^{2}$ planta técnica & 1 & 52.0 & 5.2 \\
52 m $^{2}$ cocina & 1 & 87.0 & 0 \\
Technical facilities floor & 1 & 87.0 & 87 \\
Meeting room floor & 1 & 87.0 & 43.5 \\
Lobby & Floors & $\mathbf{m}^{2}$ & Persons \\
\hline Administrative offices & 7 & 609.0 & 60.9 \\
\hline 7 floors offices & Floors & $\mathbf{m}^{2}$ & Persons \\
\hline Rest. (Public use) & 1 & 87 & 58 \\
\hline Restaurant- outlook point & 1 & 87 & 58 \\
Breakfast room & Floors & $\mathbf{m}^{\mathbf{2}}$ & Persons \\
\hline & 31 & $2,697.0$ & 390.9 \\
\hline Total & & &
\end{tabular}


Table 2: Comparison of sizing parameters according to use.

\begin{tabular}{llll}
\hline Parameters & Hotel & Offices & Renovation \\
\hline Sectorisation & $\leq 2,500 \mathrm{~m}^{2}$ & $\leq 2,500 \mathrm{~m}^{2}$ & $\leq 2,500 \mathrm{~m}^{2}$ \\
Occupation density & $20 \mathrm{~m}^{2} /$ person & $10 \mathrm{~m}^{2} /$ person & $1.5 \mathrm{~m}^{2} /$ person \\
Total density & 214 & 60,9 & 116 \\
Evacuation route & $\leq 50 \mathrm{~m}$ & $\leq 50 \mathrm{~m}$ & $\leq 50 \mathrm{~m}$ \\
Minimum stair width & $1.1 \mathrm{~m}$ & $1 \mathrm{~m}$ & $1.2 \mathrm{~m}$ \\
\hline
\end{tabular}

Table 3: Details of final dimensions of project.

\begin{tabular}{|c|c|}
\hline & Building dimensions \\
\hline Sectorisation & $\leq \mathbf{2 , 5 0 0} \mathbf{~ m}^{\mathbf{2}}$ (and/or different uses) \\
\hline Total density & 391 persons \\
\hline Resulting occupation & $\approx 6.5 \mathrm{~m}^{2} /$ person \\
\hline Evacuation route & $\leq \mathbf{5 0} \mathbf{~ m}(16.32 \mathrm{~m}$ longest route $)$ \\
\hline Stair width & $\geq \mathbf{1} \mathbf{~ m}(\mathrm{EP} \times 1 \mathrm{~m}-\mathrm{EEP} \times 1.75 \mathrm{~m})$ \\
\hline
\end{tabular}

\section{ENVIRONMENTAL IMPACTS AND CDW FROM THE RENOVATION}

The inventory phase in the life cycle contains all the mass and energy entries and outlets, emissions, definitions of the various GS-1 and GS-2 scenarios, under the same functional unit. As a result of advances in this field, the technical descriptions of the materials used in the reform are important at this stage, whereas the emission's inventory is simplified entering environmental data proceeding from environmental statements, databases or from the literature $[14,15]$. In respect of the environmental impact of transport of the materials, various stages have been taken into account, such as transport of materials and air conditioning equipment from the CIATESA plant in Montilla to the assembly point in Seville $(140 \mathrm{~km})$, and the second stage from Seville to Alicante $(595 \mathrm{~km})$. As mentioned above, some impact indicators were analysed, such as energy in the useful life of 25 years, both in GS-1 and GS-2, restoration and the structure of the stairs, enclosures, finishes and new air conditioning system and in the generation of CDW. They concerned overall consumption of GER primary energy and GWP (Table 4) overall heating potential for the two scenarios [16], and in the case of air conditioning systems for the option of four heat pumps in the roof (Climate 1) and two heat pumps in the roof and two in the technical facilities floor (Climate 2). In order to quantify the emissions in the electrical mix, the ELCD database was taken into account, according to which production of $1 \mathrm{kWh}$ electricity gives off $0.41 \mathrm{kgCO}_{2}, 0.00122 \mathrm{kgCH}_{4}$ and $0.0000465 \mathrm{kgN}_{2} \mathrm{O}$ [17]. For conversion of final energy consumption at the user point to primary energy consumption and emissions, the provisional conversion factors published by IDAE for 2010 were taken into account, specifically $2.21 \mathrm{MWh}_{\mathrm{p}} / \mathrm{MWh}_{\mathrm{f}}$ and $0.27 \mathrm{tCO}_{2} \mathrm{eq} / \mathrm{MWh}$ respectively. In all the scenarios proposed, efforts were made to reduce the production of CDW (Table 5).

As may be seen from the results obtained, the GS-1 scenario represents $47 \%$ less mass waste generation and 51\% environmental impact with respect to the GS-2 option (Table 5). 

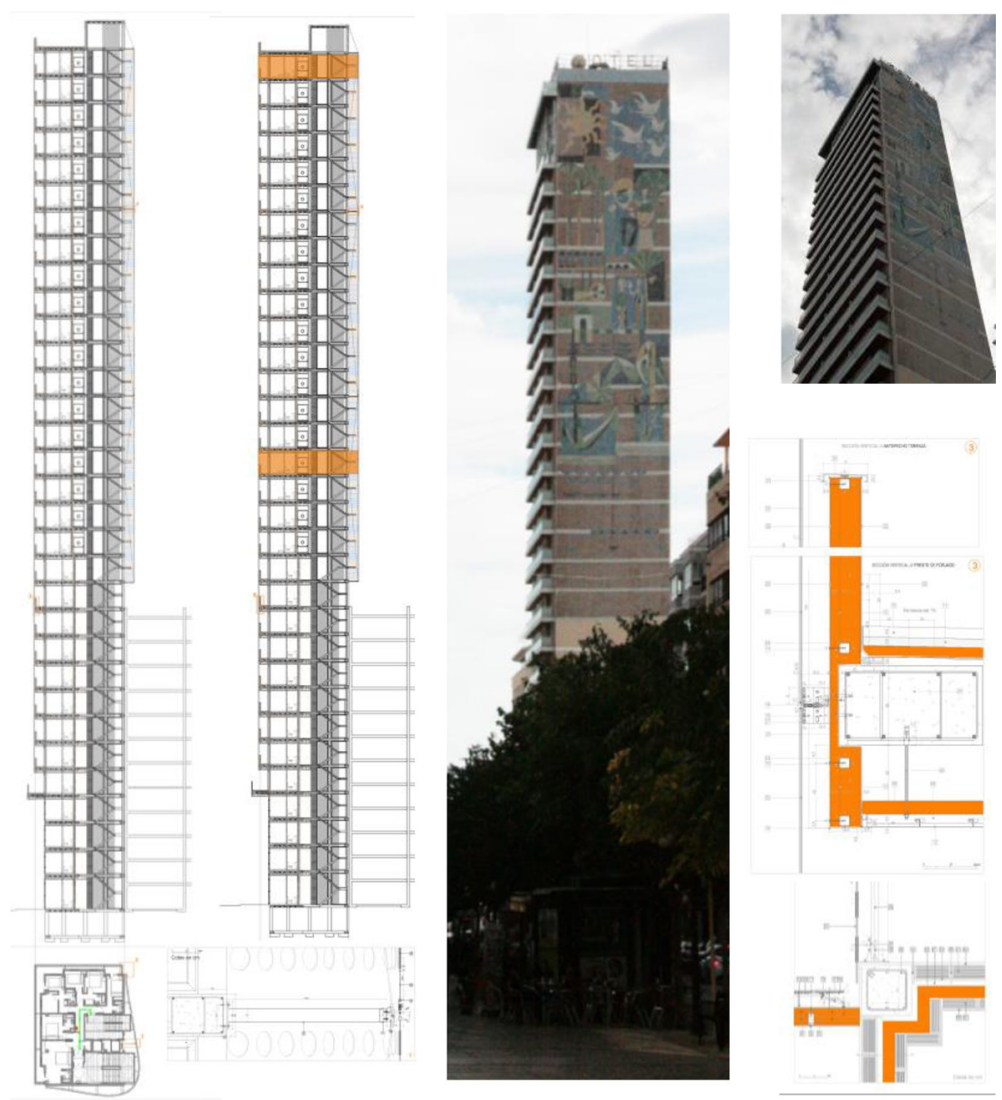

Figure 4: Image of the hotel. Section and location of the technical floor.

Personal safety would be guaranteed with a specially protected sufficiently fire resistant staircase, although it would fail to comply with CTE DB-SI given its physical dimensions. With regard to introducing a new air conditioning system, it was noted that it would be $2.3 \%$, more efficient in energy terms to locate two heat pumps on a technical facilities floor, and the GRC and GWP would be reduced by $3.1 \%$ with respect to locating four heat pumps on the roof. For amortisation of the two possible renovation scenarios, the costs of four possible combinations were calculated with or without fitting out the technical facilities floor. Table 6 shows the results and the reduction in useful $\mathrm{m}^{2}$ and rooms in the hotel. Clearly, for greater safety in the event of fire, there should be more investment and less performance of the hotel exploitation as the number of rooms would be reduced. However, it is important to highlight the fact that increased safety is a profitable added value in the long term, as it would increase demand, and this in turn would amortise the investment. In the two scenarios studied, the demolished façades could be resolved with FINSA stainless steel ceramic fabric, this solution would provide the facility with continuous ventilation improving the architectural solution of the staircase [18]. The possibility of formation of an external fire column could be resolved by following Harrison and Spearpoint's research [19], creating a safe stairway in the event of 
Table 4: GER and GWP environmental impact in the different scenarios.

\begin{tabular}{|c|c|c|c|c|}
\hline \multirow[b]{2}{*}{ Production stage } & \multicolumn{2}{|c|}{ Climate 1. GS-1 y GS-2 } & \multicolumn{2}{|c|}{ Climate 2. GS-1 y GS-2 } \\
\hline & $\begin{array}{c}\text { GER } \\
\text { (MJ/year) }\end{array}$ & $\begin{array}{c}\text { GWP } \\
\left(\mathrm{kgCO}_{2} \text { eq/year }\right)\end{array}$ & $\begin{array}{c}\text { GER } \\
\text { (MJ/year) }\end{array}$ & $\begin{array}{c}\text { GWP } \\
\left(\mathrm{kgCO}_{2} \text { eq/year }\right)\end{array}$ \\
\hline $\begin{array}{l}\text { BdC circuit to } \\
\text { fan-coil }\end{array}$ & 50,568 & 3,640 & 48,720 & 3,507 \\
\hline Transport & 3,248 & 128 & 3,248 & 128 \\
\hline Total production phase & 53,816 & 3,768 & 51,968 & 3,635 \\
\hline Use stage & & & & \\
\hline $\begin{array}{l}\text { BdC circuit to } \\
\text { Fan-coil }\end{array}$ & $2,19,492$ & 7291 & $2,12,837$ & 7,079 \\
\hline $\begin{array}{l}\text { Maintenance. Bombas, } \\
\text { filtros, válvulas }\end{array}$ & 7,536 & 675 & 7,220 & 646 \\
\hline Total use stage & $2,27,028$ & 7966 & $2,20,057$ & 7,725 \\
\hline $\begin{array}{l}\text { Construction and } \\
\text { end of life stage }\end{array}$ & 16,017 & 696 & 15,820 & 687 \\
\hline Total & 296,861 & 12,430 & 287,845 & 12,047 \\
\hline
\end{tabular}

Table 5: Environmental impact of CDW in the two different scenarios.

\begin{tabular}{|c|c|c|c|c|c|}
\hline \multirow{2}{*}{$\begin{array}{l}\text { Construction and } \\
\text { Demolition Waste } \\
\text { Reinforced concrete }\end{array}$} & \multicolumn{2}{|c|}{$\begin{array}{c}\mathbf{S}\left(\mathrm{m}^{2}\right) \\
\mathbf{U d} . \mathbf{o} \mathbf{~ m l}\end{array}$} & \multirow{2}{*}{$\begin{array}{c}\mathbf{m} \\
(\mathrm{Tm})\end{array}$} & \multirow{2}{*}{$\begin{array}{c}\text { GS-1 } \\
\text { GER (MJ) } \\
182.95\end{array}$} & \multirow{2}{*}{$\begin{array}{c}\text { GS-2 } \\
\text { GER (MJ) } \\
431.64\end{array}$} \\
\hline & 21.8 & 523.2 & & & \\
\hline Double hollow brick & 35.7 & 856.8 & 83.9 & 79.29 & 239.9 \\
\hline $\begin{array}{l}\text { Rendering with cement } \\
\text { mortar }\end{array}$ & 16.2 & 388.8 & 12. & 63.39 & 90.88 \\
\hline $\begin{array}{l}\text { Expanded polystyrene } \\
\text { insulation }\end{array}$ & 14.1 & 338.4 & 0.41 & 31.1 & 49.2 \\
\hline Gypsum plaster & 32.3 & 775.2 & 16.27 & 21.94 & 53.69 \\
\hline Terrazzo flooring & 4.6 & 110.4 & 7.62 & 9.9 & 9.9 \\
\hline Red Alicante marble flooring & 7.2 & 172.8 & 13.5 & 0 & 67.5 \\
\hline 1:6 Bonding cement mortar & 11.8 & 283.2 & 23.8 & 128.59 & 164.22 \\
\hline Ceramic tiling $15 \times 15 \mathrm{~cm}$ & 18.2 & 436.8 & 8.3 & 37.35 & 37.35 \\
\hline Wooden doors $2.02 \times 0.70 \mathrm{~m}$ & $5 \mathrm{Ud}$ & $120 \mathrm{Ud}$ & 2.07 & 6.08 & 10.14 \\
\hline China sanitary appliances & $4 \mathrm{Ud}$ & 96 & 2.4 & 22.08 & 22.08 \\
\hline $\begin{array}{l}\text { Copper piping average } \\
\varnothing 12 \mathrm{~mm} .\end{array}$ & $21 \mathrm{ml}$ & 504 & 0.59 & 20.65 & 20.65 \\
\hline PVC piping average $\varnothing 40 \mathrm{~mm}$ & $5.2 \mathrm{ml}$ & 124.8 & 0.31 & 24.8 & 24.8 \\
\hline Total & & & & 628.12 & $1,221.95$ \\
\hline
\end{tabular}


Table 6: Calculation of the investment, reduction of surface and energy demand.

\begin{tabular}{lllll}
\hline & GS-1 & GS-2 & $\begin{array}{l}\text { GS-1 } \\
\text { Tech Floor }\end{array}$ & $\begin{array}{l}\text { GS-2 } \\
\text { Tech Floor }\end{array}$ \\
\hline PEM REHABILITACIÓN & 1.153 .322 & 2.144 .433 & 1.286 .792 & 2.277 .800 \\
Demolitions + Estructura + Acabados & 362.712 & 940.800 & 424.312 & 1.002 .400 \\
FINSA + Ceramic enclosure & 259.080 & 672.000 & 307.680 & 720.600 \\
CLIMA Installation + Fire & 531.530 & 531.530 & 554.800 & 554.800 \\
Percentage & $\mathbf{5 0 . 6 \%}$ & $\mathbf{9 4 . 1 \%}$ & $\mathbf{5 6 . 5 \%}$ & $\mathbf{1 0 0 \%}$ \\
REDUCTION BUILT SURFACE & $138 \mathrm{~m}^{2}$ & $411,6 \mathrm{~m}^{2}$ & $245,7 \mathrm{~m}^{2}$ & $513,3 \mathrm{~m}^{2}$ \\
AREA M2 & & & & \\
No ROOMS IN HOTEL & 0 & 0 & 5 & 5 \\
ENERGY DEMAND kWh/m2a & 72,1 & 69,3 & 74,3 & 71,5 \\
Annual CO2 emissions in the & $153.340 \mathrm{~kg}$ & $139.232 \mathrm{~kg}$ & $154.579 \mathrm{~kg}$ & $140.526 \mathrm{~kg}$ \\
phase of Use & & & & \\
Percentage & $\mathbf{9 9 . 2 \%}$ & $\mathbf{9 0 . 1 \%}$ & $\mathbf{1 0 0 \%}$ & $\mathbf{9 0 . 2 \%}$ \\
\hline
\end{tabular}

fire. Reduction of the annual energy demand would be resolved in the stairs by providing an external coating of expanded polystyrene $4 \mathrm{~cm}$ thick and concealed behind the ceramic fabric.

\section{CONCLUSIONS}

The restoration of high-rise buildings on the Spanish Mediterranean coast requires efficient fire protection measures, due to the shortcomings in their original design. Given the environmental impact that these buildings have throughout the stages of their life cycle, the LCA methodology should be used when addressing renovation work. Due to the complexity of these methodologies, and taking into account recent studies that have quantified the repercussions of each impact indicator in this type of work, it was decided to simplify the LCA methodology applying as environmental indicators the reduction of energy demands by introducing new air conditioning installations and reducing CDW, and using return on investment as an economic indicator. In this simplified manner, specific conclusions were obtained which assist in the decision-making process when addressing a renovation project.

This methodology was applied to the hotel Gran Sol Tryp in Alicante. In the case of applying the current CTE DB-SI regulations for fire prevention, which would mean installing two new fire escape staircases (GS-2), the energy demand could be reduced by $9 \%$ compared to a single fire escape (GS-1). In terms of CDW the GS-1 scenario would mean a 50\% reduction compared to that of GS-2. The investment cost of GS-2 would be 2,144,433€, $86 \%$ higher than GS-1, with a much higher amortisation period. The installation of a technical facilities floor would be advantageous for the storage of 30,000 litres for fire fighting purposes. At the same time, it would be useful for installing the air conditioning, adding $2.3 \%$ to the efficiency system. These results would facilitate decision making in the renovation project. Efforts should be made to implement the GS-1 scenario, with a technical facilities floor for air conditioning equipment and fire fighting water tanks on floor 16. 


\section{REFERENCES}

[1] McDonough, W., The Hannover Principles: Design for Sustainability. William McDonough Architects: New York, 1992.

[2] Rogers, R. \& Gumuchdjian, P., Cities for a Small Planet. Faber \& Faber Limited: London, p. 3, 1997.

[3] Cuchí, A., Las Claves de la Sostenibilidad, en SOLANAS, Toni (coord.). Vivienda y Sostenibilidad en España, vol. I. Gustavo Gili: Barcelona, pp. 19-20, 2007.

[4] Foster, N., Preface. 3rd European Conference on Architecture. Solar Energy in Architecture and Urban Planning. Proceedings of an International Conference, Florence, p. III, 1993.

[5] Yeang, K., Ecodesign. A Manual for Ecological Design. John Wiley \& Sons, Ltd: London, p. 415, 2006.

[6] Directive 2010/31/EU. European Parliament and of the council of 19 May 2010 on the energy performance of buildings. Available online: http/eur-lex.europa.eu/LexUriServ// LexUriServ.do?uri=OJ:L:2010:153:0013:0035:EN:PDF.

[7] UNE-EN 15459:2008. Eficiencia energética de los edificios. Procedimientos de evaluación económica de los sistemas energéticos de los edificios. Madrid: AENOR, 2008.

[8] Hernández, P. \& Kenny, P., From net energy to zero energy buildings: Defining life cycle zero energy and buildings (LC-ZEB). Energy \& Buildings, 42, pp. 815-821, 2010. http://dx.doi.org/10.1016/j.enbuild.2009.12.001

[9] Oregi, X., Hernández, P., Gazulla, C. \& Isasa, M., Integrating simplified and full life cycle approaches in decisión making for building energy refurbishment: benefits and barriers. Buildings, 5(2), pp. 354-380, 2015. http://dx.doi.org/10.3390/buildings5020354

[10] Chen, Y., Chuang, Y., Huang, C., Lin, C. \& Chien, S. The adoption of fire safety management for upgrading the fire safety level of existing hotel buildings. Building and Environment, 51, pp. 311-319, 2012. http://dx.doi.org/10.1016/j.buildenv.2011.12.001

[11] Chow, W. \& Hung, W., Scheme for determining additional fire safety provisions for tall buildings. Journal of Applied Fire Science, 19(4), pp. 341-367, 2009. http://dx.doi.org/10.2190/AF.19.4.d

[12] Bernat-Masó, E., Gil, L., Roca, P., Sarrablo, V. \& Escrig, C., Structural characterisation of textile ceramic technology used as a curtain wall. Engineering Structures, 57, pp. 277-288, 2013. http://dx.doi.org/10.1016/j.engstruct.2013.09.018

[13] Firlag, S. \& Zawada, B., Impacts of airflows, internal heat and moisture gains on accuracy of modeling energy consumption and indoor parameters in passive building. Energy and Buildings, 64, pp. 372-383, 2013. http://dx.doi.org/10.1016/j.enbuild.2013.04.024

[14] Swiss Centre for Life Cycle Inventories, Ecoivent 3, https://ecoquery.ecoivent.org/File/ Reports

[15] ISO 14040, Environmental Management-Life Cycle Assessment-Principles and Framework, 2006.

[16] Assiego, R., Calleja, G., Cejudo, J.M., Raugei, M., Fullana, I. \& Palmer, P., A decisionmaking LCA for energy refurbishment of buildings. Conditions of comfort. Energy and Builidngs, 70, pp. 333-342, 2014.

http://dx.doi.org/10.1016/j.enbuild.2013.11.049 
[17] ELCD Database, www.eplca.jcr.ec.europa.eu/ELCD3/index.xhtml;jsession id=9FC03 F3B6A0A5F8252F667E462DF467C

[18] Padilla-Marcos, M.A., Feijó-Muñoz, J. \& Meiss, A., Wind velocity effects on the quality and efficiency of ventilation in the modelling of outdoor spaces. Case studies. Journal of Building Services Engineering Research \& Technology, 37, pp. 33-50, 2015. http://dx.doi.org/10.1177/0143624415596441

[19] Harrison, R. \& Spearpoint, M., A comparison between channelled and unchannelled balcony spill plumes. Journal of Building Services Engineering Research \& Technology, 31(3), pp. 265-277, 2010. 